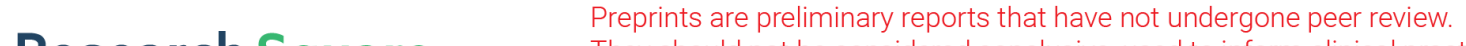 They should not be considered conclusive, used to inform clinical practice, or referenced by the media as validated information. \\ Development of A Novel Expression System In Lactic Acid Bacteria Controlled By A Broad-Host- Range Promoter $P_{\text {srfa }}$
}

\section{Chengran Guan}

Yangzhou University https://orcid.org/0000-0001-6145-2949

\section{Yuan Yuan}

Yangzhou University

\section{Yan Ma}

Yangzhou University

\section{Xin Wang}

Shandong Yinfeng Life Science Research Institute

Chenchen Zhang

Yangzhou University

\section{Maolin Lu}

Yangzhou University

\section{Ruixia Gu}

Yangzhou University

Dawei Chen ( $\square$ yzdwchen@163.com )

Yangzhou University https://orcid.org/0000-0002-6668-6434

\section{Research}

Keywords: Broad-host-ranged promoter, expression system, lactic acid bacteria, heterologous expression

Posted Date: August 17th, 2021

DOl: https://doi.org/10.21203/rs.3.rs-810045/v1

License: (c) (i) This work is licensed under a Creative Commons Attribution 4.0 International License. Read Full License

Version of Record: A version of this preprint was published at Microbial Cell Factories on February 15th, 2022. See the published version at https://doi.org/10.1186/s12934-022-01754-z. 


\section{Abstract}

\section{Background:}

Latic acid bacteria ( $L A B)$ are exploited for development of gene expression system owing to its health promoting properties and a high degree of safety status. Most of the expression systems were constructed in Lactobacillus lactis with inducible promoters. It is necessary to exploit novel promoters to develop LAB host platforms which are indispensable in dairy and health application to satisfy the production demand of increased number of target-genes. Previously, promoter $P_{\text {srfa }}$ had been displayed broad host range and used to construct auto-inducible expression system in B. subtilis and $E$. coli. In this work, the feasibility of $P_{\text {srfa }}$ in lactic acid bacteria (LAB) was estimated.

\section{Results:}

Plasmid with the green fluorescent protein (GFP) inserting downstream of $\mathrm{P}_{\text {srfa }}$ was transformed into $L$. casei 5257, L. plantarum 97, L. fermentum 087 and Weissella confusa 10, respectively. The recombinant strains grew well and displayed different fluorescence which could be detected by spectrophotometer and laser scanning confocal microscope. Moreover, the promoter activity was strain-specifically influenced by particular carbon and nitrogen sources. Heterologous laccase CotA could be expressed by $\mathrm{P}_{\text {srfa }}$ in $L$. casei 5257-05 and $L$. plantarum 97-06. By adjusting the $\mathrm{pH}$ value from 4.5 to 6.5 during incubation, the CotA activity of $L$. plantarum $97-05$ and $L$. casei $5257-05$ was increased by $137.7 \%$ and $61.5 \%$, respectively. Finally, the fermentation $\mathrm{pH}$ was variably up-regulated along with the production of NADH oxidase controlled by the $\mathrm{P}_{\text {srfA }}$ and its derivative mutated with core regions.

\section{Conclusions:}

These data suggested that $P_{\text {srfA }}$ was valid for gene expression in different species of LAB. Moreover, $P_{\text {srfA }}$ could be used as an attractive candidate for fine-tuning gene expression in a broad range of procaryotic expression plants.

\section{Introduction}

Expression host systems are developed for the expression of heterologous proteins and are becoming more and more attractive along with the development of molecular biology and the emergence of the synthetic biology [1]. So far, the extensively used expression systems were developed in E. coli, Bacillus subtilis and Saccharomyces cerevisiae due to their specific genetic background, mature genetic manipulation and capacity for continuous fermentation [2, 3]. As the developed expression systems are generally have inherent advantages and drawbacks, it is necessary to exploit novel expression host platforms to satisfy the demand of producing the increased number of target-genes for various industrial productions. 
Lactic acid bacteria (LAB) are a heterogeneous group of bacteria characterized by their ability to produce lactic acid as a fermentation product, including genera such as Lactococcus, Lactobacillus and Streptococcus. LAB are exploited for development of gene expression system owing to its health promoting properties and a high degree of safety status [4,5]. Recently, remarkable achievements have been made towards the development of genetic engineering tools and therapeutic delivery systems to produce many different proteins of health interest, such as antigens, cytokines, vitamin, etc [6-8]. The most successfully and widely used expression system is NICE (nisin controlled gene expression) system in $L$. lactis using promoter $P_{\text {nisA }}$ which is proved to be a valuable tool for production of heterologous proteins including antimicrobial peptides, membrane proteins and vaccines [9]. Besides, some other inducible expression systems were constructed in $L A B$ with promoters activated by lactose $\left(P_{\text {lacA }}\right)$, zinc $\left(P_{z n}\right)$, xylose $\left(P_{x y \mid T}\right)$, fructo-oligosaccharide $\left(P_{f o s}\right)$, etc [10]. However, limited constitutive promoters were isolated which were able to be used for the production of food additives or application in the intestinal environment as $L A B$ comprise a probiotic background. For example, promoter $\mathrm{P}_{11}$ (a synthetic sequence based on an rRNA promoter from L. plantarum WCSF1), promoter $\mathrm{P}_{\text {tuf33 }}$ and $\mathrm{P}_{\text {tuf34 }}$ (the promoter regions upstream of the gene encoding the putative translation elongation factor TU from L. plantarum CD033 and from L. buchneri CD 034) were demonstrated to be feasible for strong constitutive gene expression in L. plantarum [11].

The preferred expression system is selected depending upon the required quality and quantity of the target protein. Furthermore, the cost, availability and convenience of an optimal expression system should also be taken into consideration before making an informed choice of a system with which to express a foreign protein [12]. To take an optimal expression system, it is necessary to evaluate the preliminary expression of the interest gene in the possible host cells. As the developed host cells have inherent genetic diversity, construction of cross-species expression system using the same genetic tools is a time- and cost-saving strategy to select the preferred expression cell for the target gene. The promoter, playing the role of expression switch, is commonly strain and context specific and can vary significantly within species. Only a limited number of promoters have been used in a broad range species, such as $\mathrm{P}_{T 7}, \mathrm{P}_{x y l}, \mathrm{P}_{l a c}$ and $\mathrm{P}_{B A D}$, etc [13-15]. Hence, promoters available for Gram-positive and Gramnegative host strains should be developed to simultaneously examine gene expression in different genetic and physiological backgrounds and thus identify the most suitable expression strain. To date, $\mathrm{P}_{11}$ showed cross species activity in $L$. plantarum and $L$. sakei and promoter $\mathrm{P}_{\text {tuf }}$ was demonstrated highly active in some tested Lactobacillus strains which was also recognized in E. coli [16].

Hitherto, the development of genetic engineering tools and the molecular characterization have been mainly made in L. lactis [5]. Some other LAB are indispensable in dairy and health applications which are potential to be used as production organisms for antimicrobials, exopolysaccharides, flavor-compound and texturing compound. Previously, the promoter of the srf operon ( $\left.\mathrm{P}_{\text {srfA }}\right)$ originated from B. subtilis, had been used to construct expression systems in $B$. subtilis and $E$. coli and heterologous proteins were highly produced without inducer $[17,18]$. In this work, promoter $P_{\text {srfA }}$ was used for construction of expression systems in LAB. The feasibility of promoter $P_{\text {srfA }}$ was studied including the range of host strains, the 
factors affecting the promoter strength and the applicability of producing heterologous proteins. This work will enrich the efficient genetic toolbox for gene expression in LAB. Meanwhile, it will be helpful for cross-species gene expression or module construction in E. coli, B. subtilis and LAB.

\section{Materials And Methods}

\section{Strains, plasmids and incubated conditions}

The bacterial strains and plasmids used in this study are listed in Table 1. E. coli JM109 was used as a host for gene cloning. L. casei 5257, L. plantarum 97, L. fermentum 087 and Weissella confusa 10 were used for the gene expression. The vector $\mathrm{pCold} \mathbb{\mathrm { V }} \mathrm{Z} Z \mathrm{Z}$ containing gene cotA for enzyme Laccase was kindly given by Zhang Y.Z. (Yancheng Institute of Technology, Jiangsu, China). The media used for E. coli and LAB were LB (Luria-Bertani) medium and MRS (de Man, Rogosa and Sharp) medium. When appropriate, growth media for recombinant strains were supplied with ampicillin $(10 \mu \mathrm{g} / \mathrm{mL})$ and chloramphenicol $(10$ $\mu \mathrm{g} / \mathrm{mL})$.

Table 1

Plasmids used in this study

\begin{tabular}{|c|c|c|}
\hline Plasmids & Characteristics & Reference \\
\hline pMY01 & pNE8148 with $\mathrm{P}_{\text {nisA }}$ replaced by the fragment of $\mathrm{P}_{\text {srfa }}-g f p$ & [18] \\
\hline pCold $\nabla-Z$ & $\mathrm{pCold} \nabla$ with gene $\cot A$ & This work \\
\hline pMY05 & pMY01 with gene $g f p$ replaced by gene $\cot A$ & This work \\
\hline pMY06 & pMY01 with gene $g f p$ replaced by gene nox2 & This work \\
\hline pMY07 & pMY06 containing promoter P07 (-35 region of $\mathrm{P}_{\text {srfa }}$ mutated into TTGACA) & This work \\
\hline pMY08 & pMY06 containing promoter P08 (-10 region of $\mathrm{P}_{\text {srfA }}$ mutated into TATAAT) & This work \\
\hline pMY09 & $\begin{array}{l}\text { pMY06 containing promoter P09 ( }-35 \text { and }-10 \text { regions of } \mathrm{P}_{\text {srfA }} \text { mutated into } \\
\text { TTGACA and TATAAT) }\end{array}$ & $\begin{array}{l}\text { This work } \\
\text { This work }\end{array}$ \\
\hline $\begin{array}{l}\text { pMY11 } \\
\text { pMY12 }\end{array}$ & $\begin{array}{l}\text { pMY06 containing promoter } \mathrm{P} 10 \text { (the RBS region of } \mathrm{P}_{\text {srfA }} \text { mutated into } \\
\text { TAAGGAGG) }\end{array}$ & This work \\
\hline & $\begin{array}{l}\text { pMY06 containing promoter P11 (the CodY site of } P_{\text {srf }} \text { deleted with } 20 \mathrm{bp} \text { ) } \\
\text { pMY06 containing promoter P12 ( } \mathrm{P}_{\text {sffA }} \text { deleted the CodY sites) }\end{array}$ & \\
\hline
\end{tabular}

\section{Recombinant DNA techniques}

Plasmid construction was performed in E. coli and DNA extraction was performed by following a standard procedure as previously described [17]. Recombinant plasmids were transformed into LAB as 
previously described [16]. The primers used in this study are listed in Table 2. PCR was performed using primerSTAR max DNA polymerase (Takara, Japan). All of the recombinant plasmids constructed in this work were confirmed by DNA sequencing (Shanghai Sangon Biotech Co., Ltd., China).

Table 2

Sequence of primers used in this study

\begin{tabular}{|c|c|}
\hline Primers & Sequence \\
\hline $\mathrm{F} 1$ & CATTGTCATACCTCCСCTAAT \\
\hline R1 & GGCACTCACCATGGGTACT \\
\hline F5 & GCTTATAAAGATTAGGGGAGGTATGACAATGATGAACCTAGAAAAGTTTG \\
\hline R5 & GCATGCCTGCAGTACCCATGGTGAGTGCCCTAAATGATATCCATCGGCC \\
\hline F6 & AAAGATTAGGGGAGGTATGACAATGATGAAAGTTGCCATTATTGG \\
\hline R6 & TGCCTGCAGTACCCATGGTGAGTGCCTTAATTATTCCGACGATAGC \\
\hline F7 & TGAAACTTTTCACCCATTTTTCGTTGACAAAAACATTTTTTTCATT \\
\hline R7 & CAGTTTAAATGAAAAAAATGTTTTTGTCAACGAAAAATGGGTGAAAAG \\
\hline F8 & GGTGATAAAAACATTTTTTTCATTTATAATGAACGGTAGAAAGAT \\
\hline R8 & TATTTTTTATCTTTCTACCGTTCATTATAAATGAAAAAAATGTTT \\
\hline F9 & TGAAACTTTTCACCCATTTTTCGTTGACAAAAACATTTTTTTCATT \\
\hline R9 & CATTATAAATGAAAAAAATGTTTTTGTCAACGAAAAATGGGTGAAAAG \\
\hline F10 & GCACATGTTCACTGCTTATAAAGTAAGGAGGTATGACAATGATGAAAG \\
\hline R10 & GGCAACTTTCATCATTGTCATACCTCCTTACTTTATAAGCAGTGAAC \\
\hline F11 & TTCATTTAAACTGAACGGTAAACAATGAATAAATAGCCAAAATTGGTT \\
\hline R11 & TTGGCTATTTATTCATTGTTTACCGTTCAGTTTAAATGAAAAAAATGT \\
\hline F12 & TTCATTTAAACTGAACGGTATCTTATTAGGGTGGGGTCTTGCGGTCT \\
\hline R12 & AAGACCCCACCCTAATAAGATACCGTTCAGTTTAAATGAAAAAAATGT \\
\hline
\end{tabular}

Plasmid pMY01 was linearized using inverse PCR with primers F1 and R1. Gene cotA flanked by a 30-bp homology sequence upstream and downstream of the inserted position in pMY01 was amplified from

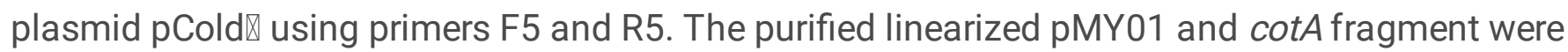
connected according to the manufacturers' protocols of the Clone ExpressTM II One Step Cloning Kit (Vazyme Biotech Co., Ltd, Nanjing, China). The product was transformed into E. coli and the sequenced clone was named as pMY05. To construct plasmid pMY06 was constructed according to the steps described above. Gene nox was cloned from L. plantarum genome using primers F6 and R6 which was then connected with the purified linear pMY01, yielding plasmid pMY06. 
To construct the plasmids containing $\mathrm{P}_{\text {srfa }}$ with mutation in the core region, plasmid pMY06 was used as the template by means of a megaprimer PCR as previously described [18]. The derivatives of pMY06 (from pMY07 to pMY12 containing the related promoters P07 to P12) with mutation in the core sequence of the promoters were obtained with the corresponding primers.

\section{Cultivation of LAB}

A single colony of the appropriate recombinant LAB strain was picked from an MRS agar plates, inoculated in $10 \mathrm{~mL}$ of MRS liquid medium and cultured at $37^{\circ} \mathrm{C}$ for $24 \mathrm{~h}$. Then, $0.3 \mathrm{~mL}$ of the culture were inoculated in $10 \mathrm{~mL}$ of MRS liquid medium and cultured at $37^{\circ} \mathrm{C}$ for $12 \mathrm{~h}$ to serve as a preculture. Then, $6 \mathrm{~mL}$ of the preculture was transferred to $250-\mathrm{mL}$ flasks that contained $200 \mathrm{~mL}$ of MRS liquid medium and cultivated at $37^{\circ} \mathrm{C}$ for $24 \mathrm{~h}$ during which the culture medium was sampled with time intervals. After cultivation, the cells and the supernatant were separated by centrifugation. The supernatant was used for $\mathrm{pH}$ detection. The harvested cells were washed by PSB buffer (50 mM Tris$\mathrm{HCl}, 100 \mathrm{mM} \mathrm{NaCl}, \mathrm{pH} \mathrm{7.5)}$ for three times, and suspended in an appropriate diluted ratio to be used for detection of fluorescence and enzyme activity.

\section{Detection of cell growth and $\mathrm{pH}$}

The cell density was determined by measuring the OD600 with a UV-1800/PC spectrophotometer (MAPADA Instrument Co., Shanghai, Ltd., China). The $\mathrm{pH}$ was measured using a laboratory pH meter (Mettler Toledo FE20, Shanghai, China). Each trial was performed in triplicate.

\section{Effect of carbon source, nitrogen source and $\mathrm{pH}$}

To analyze the effect of carbon and nitrogen sources, MRS medium with glucose was separately replaced by the equal weight of maltose, fructose and lactose while tryptone replaced by equal weight of soy peptone and polypeptone, respectively. To assay the effect of the $\mathrm{pH}$, sodium hydroxide solution (3 $\mathrm{mol} / \mathrm{L}$ ) was used to control the $\mathrm{pH}$. The strains were cultivated in the MRS medium with the initial $\mathrm{pH}$ of $6.5,7.2,8.0$ and 9.0 to analyze the effect of the initial pH. Besides, to evaluate the effect of the $\mathrm{pH}$ during fermentation, the strains were cultivated in the MRS medium and then the $\mathrm{pH}$ were separately regulated to $5.5,6.5$ and 7.5 when the $\mathrm{pH}$ declined to 4.5 during cultivation. For the above cultivation, assays were done with the usual procedure.

\section{Assay of GFP fluorescence}

The fluorescence and the image of the harvested cells were separately detected by spectrophotometer and laser scanning confocal microscope as previously described [18]. All the data were averaged from three independent samples of the same time points.

\section{Assay for NADH oxidase}


Three milliliters of the preculture of the suitable strains were incubated in a $250-\mathrm{mL}$ flask loading $100 \mathrm{~mL}$ MRS medium and cultivated in a shaker incubator at rotate speed of $120 \mathrm{r} / \mathrm{min}$ at $37^{\circ} \mathrm{C}$ for $15 \mathrm{~h}$. The sample was obtained at $3 \mathrm{~h}, 9 \mathrm{~h}$ and $15 \mathrm{~h}$. After centrifugation, the supernatant and the cells were used for detection of $\mathrm{pH}$ and the activity of $\mathrm{NADH}$ oxidase, respectively. The harvested cells were disrupted on ice by a cell disruptor (Constant System Ltd., England) and then centrifugated for $10 \min \left(4^{\circ} \mathrm{C}, 10000\right.$ $\mathrm{r} / \mathrm{min}$ ). The corresponding supernatant was used for the detection of the protein concentration and the enzyme activity according to the instruction of the NADH oxidase test kit and total protein quantitative assay kit (Jiancheng Bioengineering Institute, Nanjing, China). One unit of activity was defined as the absorbance increase equal to $0.01 \mathrm{in} 1 \mathrm{~min}$ at $600 \mathrm{~nm}$ per milligram protein. The results are the averages of triplicate assays.

\section{Results And Discussion}

\section{Feasibility of promoter $P_{\text {srfA }}$ in different species of LAB}

Genetic engineering tools used for cloning heterologous genes have mainly exploited with L. lactis which has been used as the model microorganism in LAB research. Recently, with the increased interest in the probiotic function of the $L A B$, it is necessary to develop novel expression systems which could work in a broad range of $L A B$ especially in the strains with proven probiotic [19]. Promoter $\mathrm{P}_{\text {srfA, }}$, originated from $B$. subtilis, had already been used to develop expression system for production of heterologous proteins in $B$. subtilis and $E$. coli in our previous work $[17,18]$. In this study, using the GFP as the report protein, the feasibility of $P_{\text {srfa }}$ was evaluated in four representative genera of $L A B$ which were wildly used in food production.

The recombinant plasmid pMY01 containing the fragment $\mathrm{P}_{\text {srfa }}-g f p$ was separately transformed into $L$. casei 5257, L. plantarum 97, L. fermentum 087 and $W$. confusa 10 , yielding the recombinant strain $L$. casei 5257-01, L. plantarum 97 - 01, L. fermentum 087 - 01 and W. confusa $10-01$, respectively. After 24 $\mathrm{h}$ cultivation, the cell growth and the GFP expression were measured (Fig. 1). The recombinant strains grew well and displayed different fluorescence which were obviously different among the recombinant strains (Fig. 1a). The highest fluorescence was obtained from L. plantarum 97 - 01 which was 1.76-, 3.08and 3.23-times higher than that of L. casei 5257-01, L. fermentum 087-01 and W. confusa $10-01$, respectively. The fluorescence intensity (defined as fluorescence per biomass of $\mathrm{OD}_{600}$ ) of L. plantarum 97 - 01 was ranged from 1.06- to 1.49-times higher than that of the other recombinant strains. Compared with L. casei 5257, L. fermentum 087 and W. confusa 10, L. plantarum 97 was demonstrated to be the most feasible host strain to express GFP under the control of $P_{\text {srfA. }}$. It was equally shown in different studies that promoter strength was strain and context specific and could vary significantly within LAB [20]. Moreover, the recombinant strains with fluorescence could be obviously detected by laser scanning confocal microscope (Fig. 1b). These data suggested that promoter $\mathrm{P}_{\text {srfa }}$ had a broad transcriptional compatibility in different species of LAB. 


\section{The effect of carbon and nitrogen sources on the activity of promoter $\mathrm{P}_{\text {srfa }}$}

The usual used carbon and nitrogen components for the cultivation of LAB were employed to estimated their effect on the expression of GFP controlled by $P_{\text {srfa }}$. Firstly, the recombinant strains were cultivated in the medium containing glucose, maltose, fructose and lactose as the solo carbon source, respectively. The strain biomass was ranged from 0.36 (W. confusa 10 - 01 with lactose) to 2.09 (L. plantarum $97-01$ with maltose) (Fig. 2a). L. plantarum 97 - 01 showed better growth with these carbon sources than the other recombinant strains, especially than that of $W$. confusa $10-01$. In addition, L. casei 5257-01 preferred glucose and fructose while L. plantarum $97-01$, L. fermentum $087-01$ and W. confusa $10-01$ preferred maltose. Meanwhile, the fluorescence of recombinant strains was varied from $1032.95 \mathrm{Au}(W$. confusa 10 - 01 with fructose) to $9102.83 \mathrm{Au}$ (L. plantarum 97 - 01 with maltose). Similarly, the recombinant strains were separately cultivated in the medium containing tryptone, soy peptone and polypeptone as the solo nitrogen sources. The strain biomass and fluorescence were ranged from 0.84 (W. confusa 10 - 01 with soy peptone) to 1.89 (L. plantarum 97 - 01 with polypeptone), $7996.13 \mathrm{Au}$ (L. plantarum 97 - 01 with polypeptone) to $696.52 \mathrm{Au}$ (W. confusa 10 - 01 with polypeptone), respectively (Fig. 2b).

Moreover, the varied fluorescence intensity was not directly proportional to the changed biomass among the recombinant strains with different carbon and nitrogen sources (Fig. 2). For instance, the biomass, fluorescence and fluorescence intensity of L. plantarum 97 - 01 cultivated with maltose were $0.63-, 6.33-$ and 3.50-times higher than that of $L$. casei 5257-01, respectively. In addition, the biomass, fluorescence and fluorescence intensity of $L$. plantarum $97-01$ with maltose were $0.10-, 0.45$ - and 0.31-times than that of glucose. Moreover, to one specific stain, the difference of biomass and promoter activity with nitrogen sources were less than that of with carbon sources. These data suggested that the carbon and nitrogen source not only played an important role to the cell growth but also to the strength of the promoter $\mathrm{P}_{\text {srfa. }}$.

\section{Application of promoter $\mathrm{P}_{\text {srfA }}$ in LAB}

Expression of heterologous enzyme CotA originated from B. subtilis

In spite of feasibility in various host strains, the other crucially important criteria for a mature expression system are the capacity to produce various target proteins [18]. Here, laccase (CotA), originated from $B$. subtilis, was used to estimate the suitability of $\mathrm{P}_{\text {srf }}$ for the production of heterologous proteins in $L A B$. To express CotA, the gene fragment $\cot A$ was inserted downstream of $\mathrm{P}_{\text {sff }}$ to replace $g f p$ on plasmid pMY01. The yielded plasmid pMY05 was separately transformed into L. plantarum 97 and L. casei 5257 obtaining the recombinant strain L. plantarum $97-05$ and L. casei 5257-05, respectively. After cultivation, the enzyme activity of CotA was detected. Compared with L. plantarum 97 and L. casei 5257, enzyme activity of CotA was obviously detected from L. plantarum $97-05$ and L. casei 5257-05 (Fig. 3). The CotA activity of strain L. plantarum $97-06$ was 0.40 times higher than that of L. casei 5257-05. Laccase represent an interesting group of oxidative enzymes among various enzymes owing to their great 
potential for biotechnological and environmental applications in biodegrading fields and food industry, such as wine stabilization, baking, etc [21]. So far, laccase was mainly produced by the wild and recombinant fungus and there were scarce reports about laccase expression in LAB.

Moreover, by adjusting the $\mathrm{pH}$ of the medium to 6.5 when the $\mathrm{pH}$ reduced below 4.5 during incubation, the enzyme activity of L. plantarum $97-05$ and L. casei $5257-05$ was increased by $137.7 \%$ and $61.5 \%$, respectively. Though there was enzyme activity, the corresponding protein band could not be detected on the SDS-PAGE. Considering on CotA and promoter $\mathrm{P}_{\text {srfA }}$ originated from $B$. subtilis, one explanation for the low expression might due to the different genetic background between Lactobacilus and Bacillus. Similarly, it was reported that nattokinase originating from $B$. subtilis was expressed in L. lactis with low yield. Even though active nattokinase was markedly detected by western blotting and fibrinolytic activity analyses, it could not be detected with coomassie brilliant blue [22]. In addition, it was reported that various carbon and nitrogen sources were used to increase the production of laccase [23]. Therefore, to enhance the expression of laccase in $L A B$, the culture components and the strength of promoter $P_{\text {srf }}$ would be optimized in our subsequent work.

Expression of $\mathrm{NADH}$ oxidase to regulate the fermentation $\mathrm{pH}$

LAB produce lactic acid during fermentation and the accumulated acid is a stress for the cell growth of LAB [24]. Normally, lactic acid is produced through glycolysis by converting pyruvate to lactate during which NADH is oxidized to NAD ${ }^{+}$by NADH oxidase (NOX) to maintain a redox balance. It was reported that when NOX was overexpressed, $\mathrm{H}^{+}$was consumed as well as the reduced pyruvate to lactate flux was almost abolished [25]. Therefore, in this work, the $\mathrm{pH}$ of the supernatant was attempted to be regulated by the expression of NOX controlled by the promoter $\mathrm{P}_{\text {srfA }}$.

To express NOX, gene fragment $g f p$ on the plasmid pMY01 was replaced by gene nox obtaining plasmid pMY06. The recombinant strains L. plantarum 97-06 and L. casei 5257-06 was cultured for $15 \mathrm{~h}$ as usual procedure. During fermentation, the recombinant strains grew similar to the wild-type strains and the NOX activity was detected from both the wild-type and recombinant strains (Fig. $4 \mathrm{~b}$ and c). However, the NOX activity and fermentation $\mathrm{pH}$ measured from $L$. plantarum $97-06$ were higher than that of $L$. plantarum 97 during fermentation (Fig. 4b). The NOX activity of L. plantarum $97-06$ detected at $3 \mathrm{~h}, 9 \mathrm{~h}$ and $15 \mathrm{~h}$ was 1.03-, 0.18- and 0.24-times higher than that of L. plantarum 97, respectively. Meanwhile, the fermentation $\mathrm{pH}$ of $L$. plantarum $97-06$ measured at $3 \mathrm{~h}, 9 \mathrm{~h}$ and $15 \mathrm{~h}$ was separately $0.13,0.19$ and $0.15-\Delta \mathrm{pH}$ higher than that of $L$. plantarum 97 . These data suggested that gene nox was successfully expressed in L. plantarum 97 under the control of promoter $\mathrm{P}_{\text {srfa }}$ and the $\mathrm{pH}$ of the supernatant could be upregulated along with the expression of NOX. However, there was scarce difference of NOX activity and fermentation $\mathrm{pH}$ gap between $L$. casei 5257 and $L$. casei 5257-06 during incubation. It was speculated that gene nox expressed by promoter $P_{\text {srf }}$ in L. casei 5257 was too low to obviously affect the fermentation $\mathrm{pH}$. The data indicated that the genetic background of L. plantarum 97 was more suitable than L. casei 5257 for promoter $\mathrm{P}_{\text {srfa }}$ to trigger the expression of nox expression. 
Fine-tunning the fermentation $\mathrm{pH}$ by promoter mutation

Metabolic engineering and synthetic biology approaches are becoming more and more attractive owing to its capacity to improve industrial application of microbes [1]. Generally, comparing with strong overexpression, strategies for the fine-tuning of gene expression are required to control the aimed metabolic fluxes in metabolic engineering. The most used method for accurate regulation of gene expression is promoter engineering $[25,26]$. Here, to evaluate the validity of $P_{\text {srfa }}$ for accurate gene expression, the sequence of $P_{\text {srfa }}$ was analyzed. Commonly, a full promoter is typically composed of core promoter, spacers and regulatory elements. Specific sequence of these promoter structures is essential for the efficiency of transcription initiation and then for the expression level of a targeted gene. By sequence analysis, besides the usual core regions of -10 box, -35 box and RBS (ribosome recognition site), there was a small sequence downstream of the promoter $P_{\text {srfA }}$ which was probably the CodY binding site. CodY was a global regulatory protein which combined to numerous target promoters and repressed transcription of many genes while activated others [27]. Here, the conserved regions of the promoter $P_{\text {srfA }}$ mentioned above were mutated using plasmid pMY06 as the template (Fig. 4a). The corresponding plasmids were individually transformed into L. plantarum 97 and L. casei 5257. The cell growth of the recombinant strains was similar to the wild strains. (Fig. 4b and c). The NOX activity and of the recombinant L. plantarum 97 containing the derivatives of $P_{\text {srfa }}$ were varied from $9.02 \mathrm{U} / \mathrm{mg}$ to 62.55 $\mathrm{U} / \mathrm{mg}$ which was accordingly 1.04- and 4.99-times higher than that of L. plantarum 97 during fermentation. Correspondingly, the $\mathrm{pH}$ of the supernatant detected from the recombinant strains was approximately 0.02 - to $0.56-\Delta \mathrm{pH}$ higher than that of the wide-type strain. The mutant promoters P09 and P10 could obviously enhance the enzyme expression and the fermentation pH was markedly upregulated. However, the NOX activity and the fermentation $\mathrm{pH}$ of the recombinant strains containing promoter P11 and P12 were similar to that of $\mathrm{P}_{\text {srfA }}$. In addition, the similar varied trend of enzyme activity and $\mathrm{pH}$ was also found in the host train L. casei 5257. Likewise, Guo constructed a constitutive promoter library by randomizing the - 35 and - 10 region of the promoter sequence of the noxE gene $\left(\mathrm{H}_{2} \mathrm{O}\right.$-forming $\mathrm{NADH}$ oxidase) in L. lactis and the fermentation $\mathrm{pH}$ was fine-tunned ranging from 5.93 to 6.32 [25]. These data demonstrated that the core regions of $P_{\text {srfA }}$ were valid in $L A B$ exhibiting different promoter strength and were able to regulate the fermentation $\mathrm{pH}$ by governing the expression of NOX.

The main focus of metabolic engineering has been on E. coli and $S$. cerevisiae as microbial workhorse. Recently, LAB has gained increasing attention because of its indispensable in dairy and health applications. Firstly, many engineering efforts were made concentrating on L. lactis in which the glycolytic highway and its uncoupling of other catabolic pathways were efficiently rerouted resulting in the high level production of both natural and novel end products, such as vitamin, polyol, extracellular polymeric substances, etc [28]. But there were only a few genetic tools developed in other LAB except $L$. lactis which were used in probiotic products. Secondly, most expression system developed in LAB were using inducible promoters, such as $\mathrm{P}_{\text {nisA }}, \mathrm{P}_{\mathrm{zn}}, \mathrm{P}_{\text {lac }}, \mathrm{P}_{170}$ which were induced by nisin, heavy metals, sugar and $\mathrm{pH}$, respectively [29-32]. Inducible expression can be preferable in cases where the aim is to overproduce a desired protein at high levels, e.g. at a specific moment during fermentation. However, as 
LAB comprise a food grade background, inducible systems are less suitable in the intestinal environment or when steady-state gene expression is required, instead, constitutive promoters providing expression of a target gene at a suitable level are desirable [33]. In addition, constitutive promoters are preferred to construct synthetic promoter library for the fine-tuning of gene expression which is important for applications as metabolic optimization and metabolic control analysis [34, 35].

In general, promoter $\mathrm{P}_{\text {srfA }}$ used in this work was able to constitutively trigger gene expression at distinct times during growth in different species of $\mathrm{LAB}$. Moreover, $\mathrm{P}_{\text {srfa }}$ had been proved to be valid to express various heterologous proteins in $B$. subtilis and $E$. coli. Thus, promoter $\mathrm{P}_{\text {srfA }}$ was feasible for the construction of circuits functional in multiple species as well as convenient preliminary screening of before deployment in E. coli, Lactobacillus spp. or Bacillus spp.

\section{Conclusion}

Developing of genetic engineering tools for gene expression have been mainly made in L. lactis and the limited Lactobacillus spp. In this work, promoter $\mathrm{P}_{\text {srfa }}$ originated from $B$. subtilis, was verified to be valid to trigger the expression of GFP and heterologous protein CotA in a broad range of LAB. Moreover, $P_{\text {srfA }}$ and its derivatives were able to accurately tune the fermentation $\mathrm{pH}$ by managing the production of NOX. Besides, in our previous work, promoter $\mathrm{P}_{\text {srfa }}$ was available to produce heterologous proteins in different genus of $B$. subtilis and $E$ coli. Hence, promoter $\mathrm{P}_{\text {srfA }}$ could be used as an attractive candidate in metabolic engineering for tuning gene expression in broad range of prokaryotic expression plant.

\section{Declarations}

\section{Ethics approval and consent to participate}

Not applicable.

\section{Consent for publication}

Not applicable.

\section{Availability of data and material}

All data used this study are included in this published article.

\section{Competing interests}

The authors declare that they have no competing interests. 


\section{Funding}

The investigation was supported by a Project Funded by the Natural Science Foundation of Jiangsu Province (BK20170496), the National Natural Science Foundation of China (31700079) and the fund of China Scholarship Council.

\section{Authors' contributions}

CG supervised the experiment and wrote the draft manuscript, $Y Y$ accomplished the determination of the recombinant expression system and analyzed the data; YM constructed the recombinant vectors; RG and $\mathrm{CZ}$ participated in the detection of gene expression; XW polished the draft manuscript; $\mathrm{ML}$ and DC conceived of the study, participated in its design, and coordination. All authors read and approved the final manuscript.

\section{Acknowledgements}

The authors want to thank Zhang Y.Z. (Yancheng Institute of Technology, Jiangsu, China) for giving us the vector $\mathrm{pCold} \rrbracket-Z$.

\section{References}

1. van Tilburg AY, Cao H, van der Meulen SB, Solopova A, Kuipers OP. Metabolic engineering and synthetic biology employing Lactococcus lactis and Bacillus subtilis cell factories. Curr Opin Biotechnol. 2019; 59:1-7.

2. Navale GR, Dharne MS, Shinde SS. Metabolic engineering and synthetic biology for isoprenoid production in Escherichia coli and Saccharomyces cerevisiae. Appl Microbiol Biotechnol. 2021; 105:457475.

3. Liu Y, Liu L, Li J, Du G, Chen J. Synthetic biology toolbox and chassis development in Bacillus subtilis. Trends Biotechnol. 2019; 37:548-562.

4. Douglas GL, Goh YJ, Klaenhammer TR. Integrative food grade expression system for lactic acid bacteria. Methods Mol Biol. 2011; 765:373-387.

5. Kleerebezemab M, Hols P, Hugenholtz J. Lactic acid bacteria as a cell factory: rerouting of carbon metabolism in Lactococcus lactis by metabolic engineering. Enzyme Microb Technol. 2000; 26:840-848.

6. Reuter MA, Hanniffy S, Wells JM. Expression and delivery of heterologous antigens using lactic acid bacteria. Methods Mol Med. 2003; 87:101-114. 
7. Gackowska L, Michalkiewicz J, Krotkiewski M, Helmin-Basa A, Kubiszewska I, Dzierzanowska D. Combined effect of different lactic acid bacteria strains on the mode of cytokines pattern expression in human peripheral blood mononuclear cells. J Physiol Pharmacol. 2006; 57 Suppl 9:13-21.

8. Sybesma W, Starrenburg M, Kleerebezem M, Mierau I, de Vos WM, Hugenholtz J. Increased production of folate by metabolic engineering of Lactococcus lactis. Appl Environ Microbiol. 2003; 69:3069-3076.

9. Mierau I, Kleerebezem M. 10 years of the nisin-controlled gene expression system (NICE) in Lactococcus lactis. Appl Microbiol Biotechnol. 2005; 68:705-717.

10. Landete JM. A review of food-grade vectors in lactic acid bacteria: from the laboratory to their application. Crit Rev Biotechnol. 2017; 37:296-308.

11. Tauer C, Heinl S, Egger E, Heiss S, Grabherr R. Tuning constitutive recombinant gene expression in Lactobacillus plantarum. Microb Cell Fact. 2014; 13:150.

12. Terpe K. Overview of bacterial expression systems for heterologous protein production: from molecular and biochemical fundamentals to commercial systems. Appl Microbiol Biotechnol. 2006; 72:211-222.

13. Karsi A, Lawrence ML. Broad host range fluorescence and bioluminescence expression vectors for Gram-negative bacteria. Plasmid. 2007; 57:286-295.

14. Wu W, Liu F, Singh S. Toward engineering E. coli with an autoregulatory system for lignin valorization. Proc Natl Acad Sci. 2018; 115:2970-2975.

15. Browning DF, Godfrey RE, Richards KL, Robinson C, Busby SJW. Exploitation of the Escherichia coli lac operon promoter for controlled recombinant protein production. Biochem Soc Trans. 2019; 47:755-763.

16. Spangler JR, Caruana JC, Phillips DA, Walper SA. Broad range shuttle vector construction and promoter evaluation for the use of Lactobacillus plantarum WCFS1 as a microbial engineering platform. Synth Biol (Oxf). 2019; 4:ysz012.

17. Guan C, Cui W, Cheng J, Zhou L, Guo J, Hu X, Xiao G, Zhou Z. Construction and development of an auto-regulatory gene expression system in Bacillus subtilis. Microb Cell Fact. 2015; 14:150.

18. Guan C, Ma Y, Chen X, Zhao R, Huang X, Su J, Chen D, Lu Z, Li Q, Gu R. Broad-host-range application of the srfA promoter from Bacillus subtilis in Escherichia coli. J Microbiol Methods. 2020; 168:105798.

19. Mays ZJ, Nair NU. Synthetic biology in probiotic lactic acid bacteria: At the frontier of living therapeutics. Curr Opin Biotechnol. 2018; 53:224-231. 
20. McCracken A, Turner MS, Giffard P, Hafner LM, Timms P. Analysis of promoter sequences from Lactobacillus and Lactococcus and their activity in several Lactobacillus species. Arch Microbiol. 2000; 173:383-389.

21. Patel N, Shahane S, Shivam, Majumdar R, Mishra U. Mode of action, Properties, production and application of laccase: A review. Recent Pat Biotechnol. 2019; 13:19-32.

22. Liang $X$, Zhang L, Zhong J, Huan L. Secretory expression of a heterologous nattokinase in Lactococcus lactis. Appl Microbiol Biotechnol. 2007; 75:95-101.

23. Kumar R, Kaur J, Jain S, Kumar A. Optimization of laccase production from Aspergillus flavus by design of experiment technique: Partial purification and characterization. J Genet Eng Biotechnol. 2016; 14:125-131.

24. Wu C, Huang J, Zhou R. Progress in engineering acid stress resistance of lactic acid bacteria. Appl Microbiol Biotechnol. 2014; 98:1055-1063.

25. Guo T, Kong J, Zhang L, Zhang C, Hu S. Fine tuning of the lactate and diacetyl production through promoter engineering in Lactococcus lactis. PLoS One. 2012; 7:e36296.

26. Nevoigt E, Kohnke J, Fischer CR, Alper H, Stahl U, Stephanopoulos G. Engineering of promoter replacement cassettes for fine-tuning of gene expression in Saccharomyces cerevisiae. Appl Environ Microbiol. 2006; 72:5266-5273.

27. Levdikov VM, Blagova E, Young VL, Belitsky BR, Lebedev A, Sonenshein AL, Wilkinson AJ. Structure of the branched-chain amino acid and GTP-sensing global regulator, CodY, from Bacillus subtilis. J Biol Chem. 2017; 292:2714-2728.

28. Papagianni M. Metabolic engineering of lactic acid bacteria for the production of industrially important compounds. Comput Struct Biotechnol J. 2012; 3:e201210003.

29. Mierau I, Olieman K, Mond J, Smid EJ. Optimization of the Lactococcus lactis nisin-controlled gene expression system NICE for industrial applications. Microb Cell Fact. 2005; 4:16.

30. Llull D, Poquet I. New expression system tightly controlled by zinc availability in Lactococcus lactis. Appl Environ Microbiol. 2004; 70:5398-5406.

31. Ma SJ, Li K, Li XS, Guo XQ, Fu PF, Yang MF, Chen HY. Expression of bioactive porcine interferonalpha in Lactobacillus casei. World J Microbiol Biotechnol. 2014; 30:2379-2386.

32. Jorgensen CM, Vrang A, Madsen SM. Recombinant protein expression in Lactococcus lactis using the P170 expression system. FEMS Microbiol Lett. 2014; 351:170-178. 
33. Rud I, Jensen PR, Naterstad K, Axelsson L. A synthetic promoter library for constitutive gene expression in Lactobacillus plantarum. Microbiology. 2006; 152:1011-1019.

34. Dehli T, Solem C, Jensen PR. Tunable promoters in synthetic and systems biology. Subcell Biochem. 2012; 64:181-201.

35. Xu N, Wei L, Liu J: Recent advances in the applications of promoter engineering for the optimization of metabolite biosynthesis. World J Microbiol Biotechnol. 2019; 35:33.

\section{Figures}

a

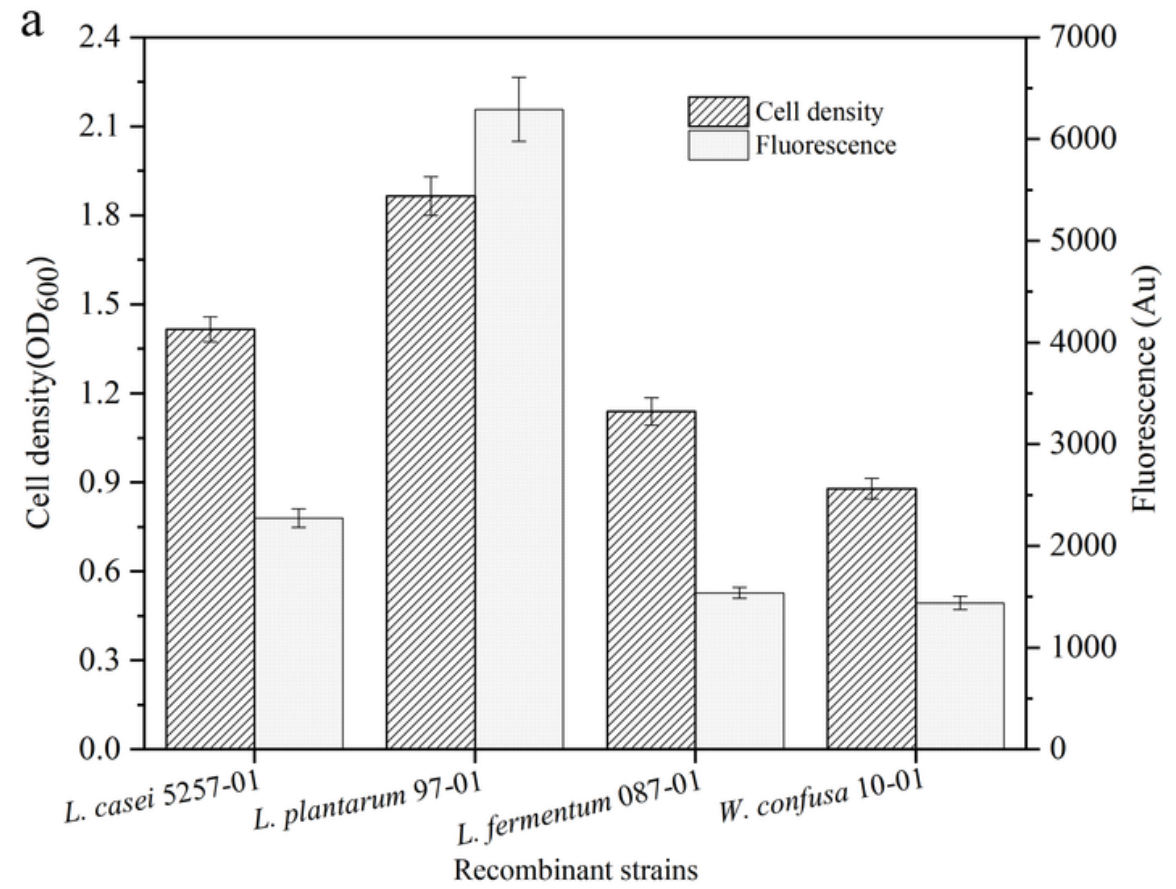

b

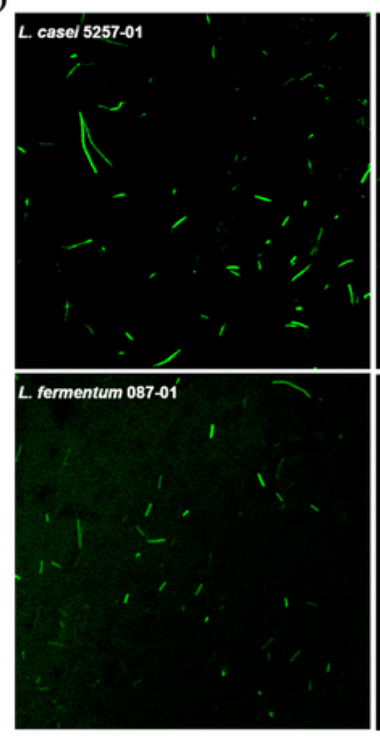

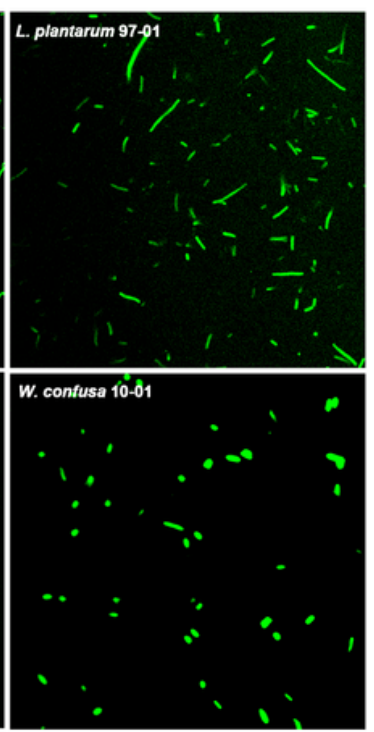

\section{Figure 1}

Expression of GFP controlled by PsrfA in recombiant LAB (a) and fluorescence analyzed by laser scanning confocal microscope (b). Plasmid pMY05 was transformed into L. casei 5257, L. plantarum 97, L. fermentum 087 and W. confusa 10, respesctively. The fluorescence and cell growth of the recombinant strains were detected. 
a

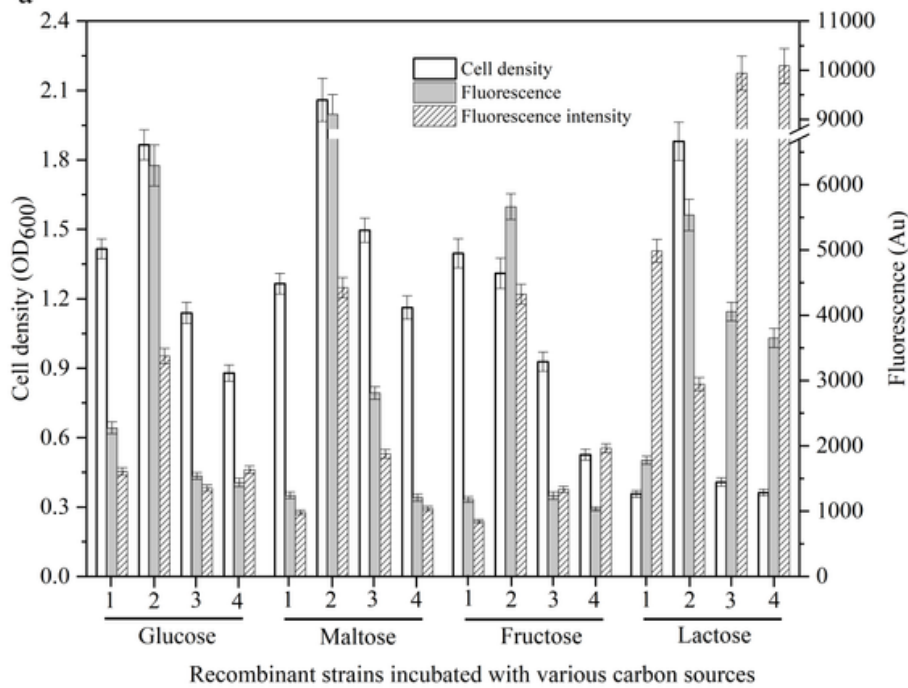

b

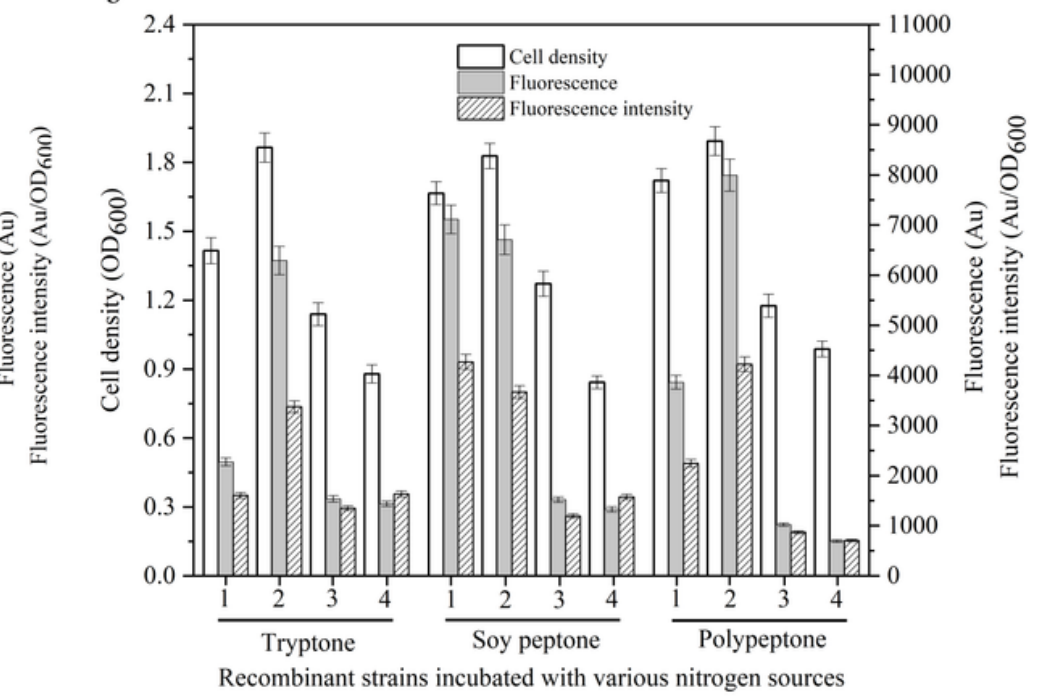

Figure 2

The effects of carbon (a) and nitrogen (b) sources on the biomass of recombinant strains and the activity of PsrfA. The recombinant strains were individually cultivated in the medium containing various carbon and nitrogen sources. The strain biomass and fluorescence were detected. 


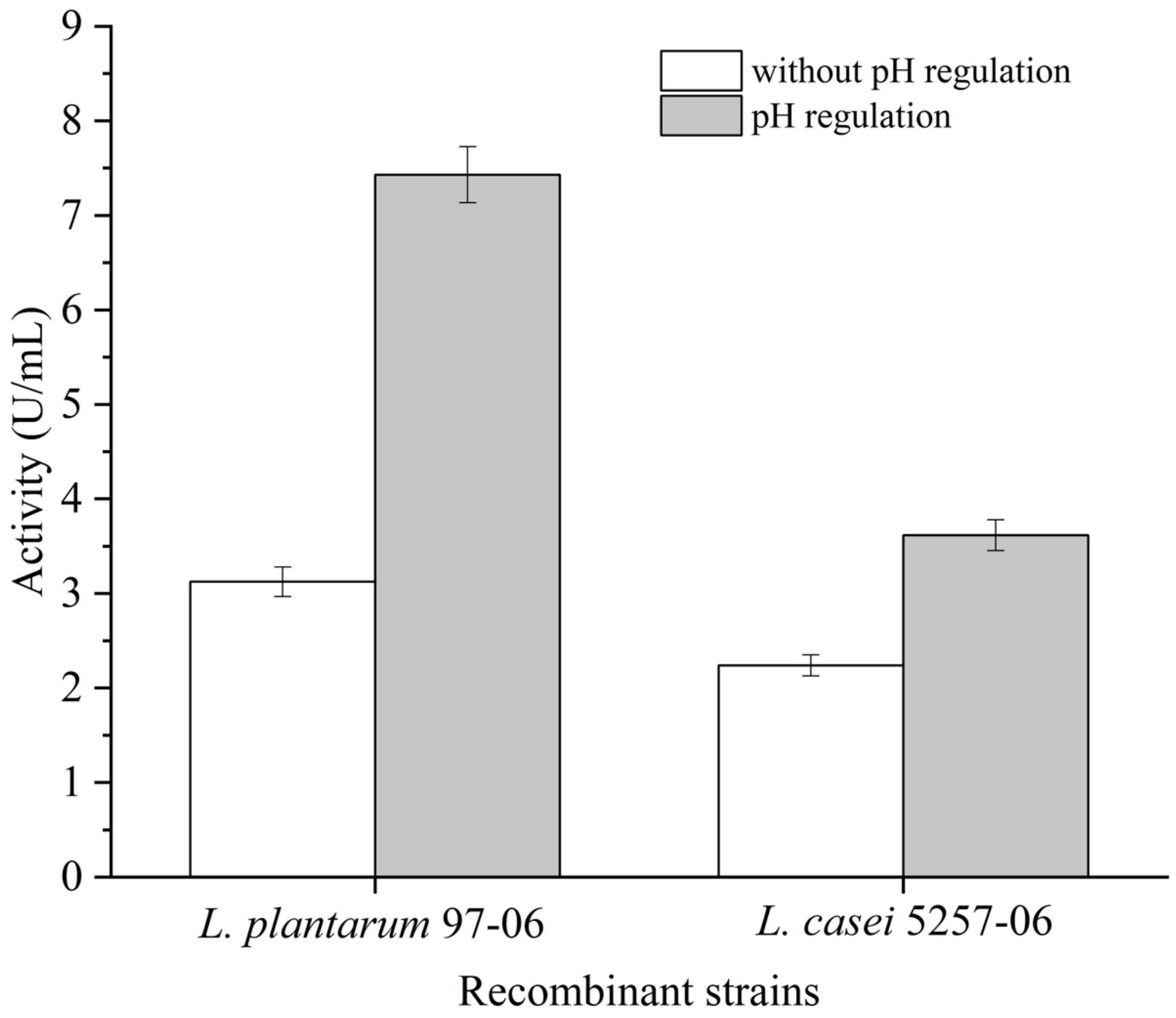

Figure 3

Expression of heterologous enzyme CotA controlled by PsrfA. The recombinant strains containing CotA were incubated and the enzyme activity was detected. Further, the expression of CotA was tested by upregulating the fermentation $\mathrm{pH}$ to 6.5 when the $\mathrm{pH}$ reduced below 4.5 during incubation. 




Figure 4

Regulation of fermentation $\mathrm{pH}$ by production of NOX. The sequence of promoter PsrfA and its derivatives (a). The recombinant plasmids containing promoter PsrfA and its derivatives were transformed into $\mathrm{L}$. plantarum 97 (b) and L. casei 5257 (c), respectively. The biomass, fermentation pH and NOX activity of the recombinant strains were detected at $3 \mathrm{~h}, 9 \mathrm{~h}$ and $15 \mathrm{~h}$ during fermentation. 